\title{
Characterization of boiler ashes from sugarcane mil
}

Sugarcane mills produce sugar and ethanol and have always used bagasse as fuel to generate energy for self-consumption. Recently some mills have been also producing surplus electricity to sell in the market a third product from sugarcane. Although any boiler can be efficient, the sale of electricity has stimulated the improvement of the burning process. However, the investment in high-pressure boilers, much more expensive than any common boiler, is essential for the exportation of electricity. Among the 22 sugarcane mills from Mato Grosso do Sul, Brazil, only 12 power plants sell electricity to the grid. The power generation efficiency depends on the pyrolysis in boilers, which results in ashes that match the unburned mineral fraction of the fuel as oxide. Both the bagasse and the straw are composed predominantly of lignin, hemicellulose and cellulose with calorific power near to the wood at the same moisture content. However the bagasse leaves the mill with about $50 \%$ of moisture while the straw reaches the industry with about $15 \%$ of humidity. This paper characterize the ashes samples from burned bagasse from seven sugarcane mills at Mato Grosso do Sul Brazilian state, to compare the methodology available for use to measure the efficiency of the pyrolysis system. Among these sugarcane mills only two are highlighted by their higher burning efficiency, both of them selling electricity, while the others showed unburned portions characterizing an inefficient system. For these industries the ash content in the ashes showed values compatible with the Superior Calorific Value as an efficiency index for the combustion degree in boilers.

Keywords: Electricity; Efficiency; Superior Calorific Value; Bagasse; Straw.

\section{Caracterização de cinzas de caldeira de usina de cana-de-açúcar}

As usinas de cana produzem açúcar e etanol e sempre usaram bagaço como combustível para gerar energia para autoconsumo. Recentemente, algumas usinas também produziram eletricidade excedente para vender no mercado um terceiro produto da cana-de-açúcar. Embora qualquer caldeira possa ser eficiente, a venda de eletricidade estimulou a melhoria do processo de queima. No entanto, o investimento em caldeiras de alta pressão, muito mais caras do que qualquer caldeira comum, é essencial para a exportação de eletricidade. Entre as 22 usinas de cana-de-açúcar do Mato Grosso do Sul, apenas 12 usinas vendem eletricidade para a rede. A eficiência da geração de energia depende da pirólise nas caldeiras, o que resulta em cinzas que correspondem à fração mineral não queimada do combustível como óxido. Tanto o bagaço quanto a palha são compostos predominantemente por lignina, hemicelulose e celulose com poder calorífico próximo à madeira com o mesmo teor de umidade. No entanto, o bagaço deixa a fábrica com cerca de $50 \%$ de umidade, enquanto o canudo chega à indústria com cerca de $15 \%$ de umidade. Este artigo caracteriza as amostras de cinzas do bagaço queimado de sete usinas de cana-de-açúcar no estado brasileiro de Mato Grosso do Sul, para comparar a metodologia disponível para uso na medição da eficiência do sistema de pirólise. Entre essas usinas de cana, apenas duas são destacadas por sua maior eficiência de queima, ambas vendendo eletricidade, enquanto as demais apresentaram porções não queimadas caracterizando um sistema ineficiente. Para essas indústrias, o teor de cinzas nas cinzas apresentou valores compatíveis com o Valor Calórico Superior como índice de eficiência para o grau de combustão em caldeiras.

Palavras-chave: Eletricidade; Eficiência; Valor Calórico Superior; Bagaço; Palha.

Topic: Desenvolvimento, Sustentabilidade e Meio Ambiente

Reviewed anonymously in the process of blind peer.
Received: $12 / 04 / 2019$

Approved: $27 / 05 / 2019$
Sheyla Thays Vieira Barcelos

Universidade Católica Dom Bosco, Brasil

http://lattes.cnpq.br/4106392653572296

sheylathays@hotmail.com

Ismael Plácido Tomielis

Universidade Católica Dom Bosco, Brasil

http://lattes.cnpq.br/2797341917026459

ismael.tomielis@gmail.com

Marli da Silva Garcia (iD

Universidade Católica Dom Bosco, Brasil http://lattes.cnpq.br/6219347221151653 http://orcid.org/0000-0002-9888-1293

marliggarcia@gmail.com
Marney Pascoli Cereda (iD)

Universidade Católica Dom Bosco, Brasil http://lattes.cnpq.br/1892208680810050 http://orcid.org/0000-0002-8181-7754

cereda@ucdb.br
Referencing this:

BARCELOS, S. T. V.; TOMIELIS, I. P.; GARCIA, M. S.; CEREDA, M. P.. Characterization of boiler ashes from sugarcane mill. Revista lbero Americana de Ciências Ambientais, v.10, n.3, p.179-190, 2019. DOI: http://doi.org/10.6008/CBPC2179-6858.2019.003.0016 


\section{INTRODUCTION}

Electricity is one of the most important tools for development, but with population growth, the traditional models of electricity generation are exhausting. The alternative energy has highlighted some renewable sources. Among them, the sugarcane crop stands out by its ability to fix carbon dioxide. In addition to the energy matrix, Brazil leads the ethanol for fuel production. In sugarcane mills and distilleries, the sugarcane bagasse is usually burned in order to supply energy for the industry self-consumption. However, in Brazil, the electricity valorization has attracted the sugarcane mills to produce energy as their third product, in addition to ethanol and sugar.

Cortez et al. (2008) report that the biomass residues have a large energy potential for power generation and highlight the need for proper exploration of these residues. The main agricultural products produced in the world, which generate large amounts of waste, are sugarcane, corn, wheat, rice, cassava and soybeans (FAOSTAT, 2010).

In all sugarcane-producing countries, the bagasse and, more recently, the straw, are usually burned as fuel to generate enough energy to ensure the self-sufficiency of sugar and alcohol production. For Pellegrini et al. (2010) the steam system based on Rankine cycle is used in all Brazilian allow the plants efficient in thermal, mechanical and electrical energy for their self-consumption. Figure 1 shows the operating system Rankine cycle adopted in the Brazilian sugar and alcohol sector.

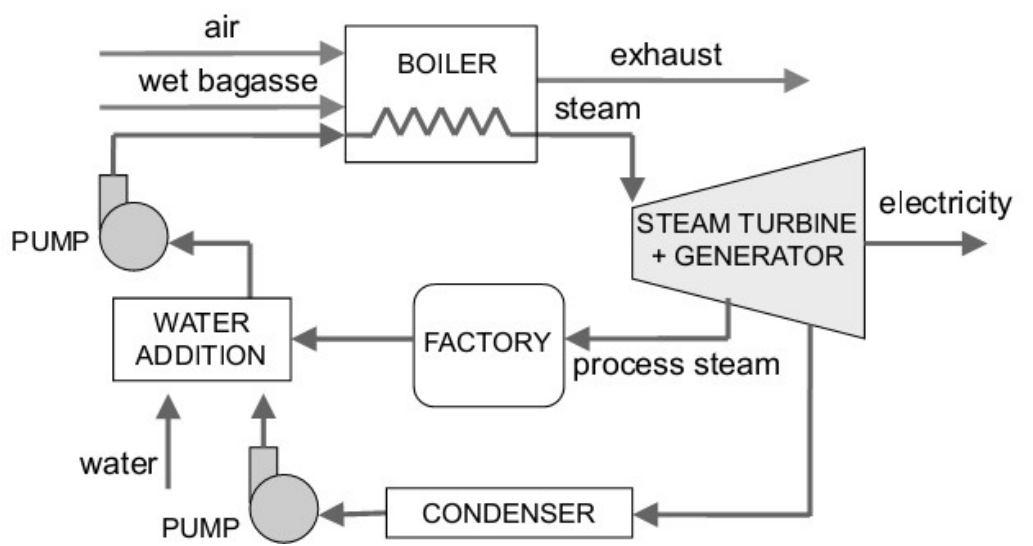

Figure 1: Diagram Rankine cycle cogeneration in the sugar and alcohol sector process.

Source: Deshmukh et al. (2013).

As Alves et al. (2015) describe that the systems used for electricity production present live steam parameters of 22 bar and $300^{\circ} \mathrm{C}$. However, more efficient systems can operate with higher live steam parameters reaching a pressure of 100 bars and the temperature of $530^{\circ} \mathrm{C}$. The steam can be expanded through the turbine to a pressure of 2.5 bar to meet the low-pressure process steam requirements of many sub-systems in the sugar and ethanol production, such as juice heating, concentration, distillation and dehydration.

Bagasse can be considered as the lignocellulosic biomass residue from the sugarcane juice extraction for ethanol or sugar production (MONCADA et al., 2013). Alves et al. (2015) report, on Table 1, the average chemical composition of the sugarcane bagasse found by Gabra et al. (2001), as well as the chemical 
composition of the straw described by Samaniego (2007). The ash composition from sugarcane wastes is similar to the mineral unburned fraction (Table 1 and 2).

Table 1: Chemical composition of sugarcane bagasse and straw.

\begin{tabular}{|l|l|l|}
\hline Chemical Composition & Sugarcane mills \\
\hline Expressed as g.100g-1 & $\begin{array}{l}\text { Bagasse } \\
\text { Gabra et al. (2001) }\end{array}$ & $\begin{array}{l}\text { Straw } \\
\text { Samaniego (2007) }\end{array}$ \\
\hline $\mathrm{SiO}_{2}$ & 72.30 & 52.62 \\
\hline $\mathrm{Al}_{2} \mathrm{O}_{3}$ & 8.00 & 15.80 \\
\hline $\mathrm{CaO}$ & 4.20 & 5.76 \\
\hline $\mathrm{Fe}_{2} \mathrm{O}_{3}$ & 6.20 & 3.93 \\
\hline $\mathrm{K}_{2} \mathrm{O}$ & 4.50 & 5.76 \\
\hline $\mathrm{MgO}$ & 2.3 & 5.27 \\
\hline $\mathrm{MnO}_{2}$ & 0.10 & $-*_{-}$ \\
\hline $\mathrm{Na}_{2} \mathrm{O}$ & 1.00 & 0.12 \\
\hline $\mathrm{P}_{2} \mathrm{O}_{5}$ & 0.90 & $-*_{-}$ \\
\hline $\mathrm{TiO}^{\mathrm{SO}}$ & 0.60 & $-*_{-}$ \\
\hline $\mathrm{SO}_{3}$ & $-*$ & 2.73 \\
\hline
\end{tabular}

Legend: - *-: without information.

Table 2: Chemical composition of ashes from sugarcane mills according to the literature.

\begin{tabular}{|c|c|c|c|c|c|}
\hline \multirow[t]{2}{*}{ Mineral } & \multirow[t]{2}{*}{ Martinera Hernández et al. (1998) } & \multicolumn{2}{|l|}{ Freitas (2005) } & \multirow[t]{2}{*}{ Ganesan et al. (2007) } & \multirow[t]{2}{*}{ Akram et al. (2009) } \\
\hline & & Sugarcane A & Sugarcane B & & \\
\hline $\mathrm{SiO}_{2}$ & 72.74 & 65.7 & 83.1 & 64.15 & 62.44 \\
\hline $\mathrm{Al}_{2} \mathrm{O}_{3}$ & 5.26 & 13.8 & 5.1 & 26.7 & 6.74 \\
\hline $\mathrm{Fe}_{2} \mathrm{O}_{3}$ & 3.92 & 4.1 & 2.6 & 5.8 & 5.77 \\
\hline $\mathrm{CaO}$ & 7.99 & 3.5 & 1.9 & 0.8 & 6.16 \\
\hline $\mathrm{Na}_{2} \mathrm{O}$ & 0.84 & $-*_{-}$ & $-*_{-}$ & 0.2 & 3.15 \\
\hline $\mathrm{K}_{2} \mathrm{O}$ & 3.47 & 8.1 & 4.5 & 2.6 & 6.87 \\
\hline $\mathrm{TiO}_{2}$ & 0.32 & $-*$ & $-*$ & $-*_{-}$ & $-*$ \\
\hline $\mathrm{MgO}$ & 2.78 & $-*-$ & $-*-$ & 0.6 & 2.97 \\
\hline $\mathrm{P}_{2} \mathrm{O}_{5}$ & 1.59 & $-*$ & $-*$ & 0.6 & $-*$ \\
\hline $\mathrm{SO}_{3}$ & $-*$ & 2.4 & 2.1 & $-*$ & 0.72 \\
\hline Lost in fire & 0.77 & 1.0 & 0.9 & 4.90 & 2.58 \\
\hline Organic carbon & 7.83 & $-*$ & $-*$ & $-{ }_{-}$ & $-*$ \\
\hline Humidity & $-*_{-}$ & $-*$ & $-*$ & $-*$ & 2.6 \\
\hline
\end{tabular}

Legend: - *-: without information

Hugot (1986) states that for energy generation in sugarcane mills, the combustible is burned in the boiler through a process known as pyrolysis. Carrier et al. (2012) clarifies that pyrolysis is a thermochemical process used in the biomass conversion into fuel, and where the biomass (bagasse, straw or both) produces ash, which is the last residue generated in the sugarcane production chain.

After the evaluation of tree sugarcane varieties, Lizcano (2015) outlines the average production of 0.54 tons of ash per hectare using direct combustion to generate electricity. This amount is equivalent to an average yield of a usable dry biomass of 38.55 tons per hectare of sugarcane production. According to Sales et al. (2010) each tone of sugarcane bagasse burned might produce $25 \mathrm{~kg}$ of ash, which is used as a fertilizer in sugarcane crops. In the boiler the more the biomass is burned, more stabilized ash is produced.

Most of the literatures about boiler ashes from sugarcane mills are related to their applications, mainly because of the large quantities generated in the pyrolysis process. Fly ash is especially used as a lowcost binder in the concrete and construction industries (AHMARUZZAMAN, 2010). In addition to the replacement of cement in concrete, fly ash has been used as an adsorbent for flue gas cleaning, treatment of wastewater, used as raw material for geopolymers synthesis, Portland cement, zeolites, and as a backfill 
material in the mining industry (AHMARUZZAMAN, 2010; DUXSON et al., 2008; TASTAN et al., 2011).

In the late 1990s, the intention of Brazilian sugar and ethanol mills was the thermal and electrical energy self-sufficiency, especially generating surplus electricity for sale to the grid (SEABRA, 2008). Until today this ashes are considered wastes, since they are used in fertilization after mixed with vinasse. Just in time the sugarcane mills started to consider the energy sold as a third commercial product, perhaps more important than sucrose or ethanol, that is why the ash from boilers became an attractive focus for further research.

The cogeneration systems of most sugarcane mills in Brazil have low surplus electricity potential due to the high consumption of steam in the process and low temperatures and pressures of live steam generated. Modern boilers with live steam parameters above 65 bar and $480^{\circ} \mathrm{C}$ and condensation turbines operating in a parallel or together with the BPST system can increase the surplus of electricity, as well as the use of sugarcane straw as a supplementary fuel (ALVES et al., 2015).

\section{MATERIALS AND METHODS}

\section{Sugar cane mills and distilleries characterization}

All seven processing sugarcane mills selected for the study are located nearby to the city of Dourados, in the Brazilian state of Mato Grosso do Sul. For ethical reasons they will be identified from A to G. All the sugarcane mills have boilers to produces energy, but the sugarcane mills $B$ and $D$ produce energy only for their self-consumption and the others produce more than 60 BAR of pression, what allow the cogeneration of electricity and the exportation of the surplus to the grid (BIOSUL, 2015).

\section{Characterization of the sugarcane mills}

Table 3 displays the characteristics of all seven sugarcane mills selected for the research. Each sugarcane mills represent a group of companies operating in Mato Grosso do Sul. The boilers represented three Brazilian manufacturers (Dedini, Zanini and HPB) and the two existing steam production systems in the state.

Table 3: Boilers and steam characteristics as informed by the seven sugarcane mills.

\begin{tabular}{|l|l|l|l|l|}
\hline & Cogeneration system & Steam pression & Steam outlet temperature & Sold energy \\
\hline Mills & Unities & $\left(\mathrm{kgf.cm}^{-2}\right)$ & $(-\mathrm{C})$ & $(\mathrm{GWh})$ \\
\hline A & BPST-C & 42 & 400 & 57,47 \\
\hline B & BPST & 24 & 310 & 0,00 \\
\hline C & BPST-C & 67 & 520 & 185,36 \\
\hline D & BPST & 21 & 310 & 0,00 \\
\hline E & BPST-C & 65 & 515 & 122,01 \\
\hline F & BPST-C & 67 & 500 & 57,87 \\
\hline G & BPST-C & 100 & 540 & $259,47\left(^{*}\right)$ \\
\hline
\end{tabular}

Legend: $\left({ }^{*}\right)$ : production of 2 boilers

The description of the boilers of the sugarcane mills was conducted through the characterization established by Alves et al. (2015) that divides the power generation systems in: BPST (Backpressure Steam Turbine System) producing steam pression lower than $60 \mathrm{kgf} \mathrm{cm}^{2}$, and BPST-C system that combines BPST 
system with CEST (Condensing-extraction Steam Turbine System), suitable for thermal powers that only make cogeneration and does not produce sugar nor ethanol.

\section{Ashes samples collection}

The ashes were collected just after the boiler output under the water-washing tower used to remove solid particulates from the air. Upon arrival in the laboratory they were dried in order to eliminate the excess of water content and to facilitate its storage. The moisture content was determined according to the normalization ABNT/NBR 6457 (1986) where is weighed 3 to $5 \mathrm{~g}$ of the sample in a porcelain crucible. The porcelain crucibles were put in an oven (mark Marconi ${ }^{\oplus}$ ) adjusted to $105^{\circ} \mathrm{C}$ with air circulation until constant weight. After cooled in the desiccator, the crucibles were weighed, and the difference was expressed as percentage. The dried samples were put in glass bottles and stored in the dark until the analysis. The analysis of particle size, density and compacted density were carried out in samples with the original particle size. Other analyses were performed on samples ground with particle size $<25$ micrometers.

\section{Samples characterization}

The samples were identified by letters ( $A$ to $G$ ) and characterized as in the following:

\section{Microscopic characterization}

The visual appearance of the samples was established in its original texture by direct observation in an optical microscope and recorded as figures. Microscope slides were prepared with the samples suspended in glycerin with safranin, as dye, which allows the differentiation of the vegetable fibbers in red.

\section{Granulometry}

The particle size profile of the samples was established by the normalization ABNT/NBR NM 248 (2003) with a Bronzinox ${ }^{\circledR}$ equipment adjusted to the maximum vibration for ten minutes. The sieves selected for this test were mesh of 4,000; 2,800; 1,000; 850; 600; 180; 90; 75; 53; $25 \mu \mathrm{m}$ and bottom. The analysis started with samples of $100 \mathrm{~g}$ and the portions retained in the sieves were weighed and expressed in percentage.

\section{Density}

The density was determined according to Methods Standard for the Examination of Water and Wastewater (APHA, 1995) as the relation mass/volume. The mass was determined in an analytical balance Shimadzu AUY 220 with an accuracy of 4 decimal places and the volume in a graduated cylinder.

\section{Tap density}

The tap density was established according to the methodology described by Bhandari et al. (1993). For this test, 10g of each sample was put in a beaker of $50 \mathrm{ml}$ and subjected to a ten-time free falls of $15 \mathrm{~cm}$ 
for sample compression. After this procedure, the volume was measured, and the tap density calculated.

\section{Colour}

It was used a colorimeter CR-400Minolta ${ }^{\circledR}$ in the Hunter Lab colour system. The colour of the samples was expressed by the coordinates B (brightness) range from black (0) to white (100) and Chroma values as a ranging from green (-) to red (+) and b ranging from blue (-) to yellow (+) as Apha (1995).

\section{Ph and alkalinity}

Both analyses are established according to Apha (1995). The pH was measured by analytical technique $4500-\mathrm{H}+$ at $\mathrm{pH}$-meter Digimed $^{\circledR}$ digital DM20, with two decimal places, and the total alkalinity was expressed in mg $\mathrm{CaCO} 3 \mathrm{~kg}-1$.

\section{Mineral analysis}

The methodology was obtained from Apha (1995). The alternative method of digestion with nitric acid was used to determine the total phosphorus content. The potassium content was determined by the analytical technique 3500-B and flame photometric determination. The contents of calcium, magnesium and nitrogen were determined according to the analytical procedure D-3500, using the method of complexion with EDTA.

Chemical analysis of the substrates was based on the methodology of organic fertilizers, which determines the total nutrient content within the analyzed material. These analyses were performed as directed by the MAPA (1988). Atomic Emission Spectrometry detection with Argon Plasma in nitric perchloric extract was used to analyze the heavy metals according to Malavolta et al. (1997).

\section{Ash content}

The ash content of the samples was determined by the method of charcoal described in the TZ TAPPI T211 om-88 (1988). The samples were heated in a muffle for 5 hours at $650^{\circ} \mathrm{C}$, cooled in a desiccator and weighed. The mass difference was expressed in percentage.

\section{Higher calorimetric value}

The higher heating value (HHV) of sample was carried out in the calorimeter bomb Calorimetry ${ }^{\circledR} \mathrm{KL}-$ 5 mark as mentioned by Doat (1977).

\section{Statistical analysis.}

The results with normal distribution values were submitted to variance analysis and the averages compared by Turkey's test at the level of $95 \%$ probability using the Statistical 7.0 software. Simple correlation among the values was also used. 


\section{RESULTS AND DISCUSSION}

Table 3 shows that the sugarcane mills B and D produce only 24 to 21 steam pression in $\mathrm{kgf} \mathrm{cm}^{-2}$, and do not sell energy. The other sugarcane mills sell variable amounts of energy from 58.00 to $259.47 \mathrm{GWh}$ (by 2 boilers). When considering only the production of energy with one boiler the values reached $185 \mathrm{GWh}$. The samples presented high humidity when collected, mainly due to the water column wash of the boiler's gases to remove the particulate (SPADOTTO et al., 2006; SOUZA et al., 2007). After drying the moisture content of the ash samples at the time of the analyses, it ranged from $0.046 \%$ to $0.508 \%$, with an average of $0.25 \%$. With the samples presenting lower humidity, the granulometry analysis was performed, what resulted in the data shown on Table 4.

Table 4 shows that the samples collected from the sugarcane mill D presented more coarse particles with nearly $40 \%$ of them larger than 4 centimetres and that were retained on the first sieve, therefore equal to or greater than $4,000 \mu \mathrm{m}$. Most samples demonstrated low retention until the $600 \mu \mathrm{m}$ mesh. Samples A, B and $E$ presented $70 \%$ of retention of particles between 90 and $600 \mu m$ meshes. The samples $C, D, E$ and $F$ concentrated more than $90 \%$ of the particle size between 180 and $25 \mu \mathrm{m}$.

Table 4: Particle size of seven samples of ash collected in sugarcane mills of Mato Grosso do Sul.

\begin{tabular}{|c|c|c|c|c|c|c|c|}
\hline \multirow{2}{*}{$\begin{array}{l}\text { Mesh } \\
(\mu \mathrm{m})\end{array}$} & \multicolumn{7}{|c|}{ Sugarcane mills (\%retained) } \\
\hline & A & B & C & $\mathbf{D}$ & $\mathrm{E}$ & $\mathbf{F}$ & $\mathbf{G}$ \\
\hline 4,000 & 5.14 & 2.00 & 0.00 & 40.47 & 0.00 & 0.39 & 0.00 \\
\hline 2,800 & 0.94 & 1.21 & 0.26 & 3.91 & 0.00 & 0.50 & 0.00 \\
\hline 1,000 & 3.02 & 8.40 & 1.26 & 5.60 & 3.87 & 1.72 & 1.07 \\
\hline 850 & 1.09 & 4.76 & 0.64 & 1.52 & 0.86 & 0.84 & 0.23 \\
\hline 600 & 2.64 & 10.85 & 0.93 & 2.68 & 1.29 & 1.16 & 0.85 \\
\hline 180 & 52.42 & 36.79 & 25.25 & 8.19 & 60.89 & 14.08 & 35.96 \\
\hline 90 & 23.74 & 20.27 & 22.90 & 7.94 & 16.37 & 24.94 & 24.66 \\
\hline 75 & 3.43 & 5.08 & 16.56 & 5.38 & 5.20 & 14.73 & 9.38 \\
\hline 53 & 2.06 & 3.39 & 12.88 & 5.74 & 3.85 & 13.53 & 7.19 \\
\hline 25 & 4.50 & 5.17 & 17.07 & 14.29 & 5.63 & 24.02 & 15.91 \\
\hline Bottom & 0.50 & 0.83 & 0.97 & 1.14 & 0.85 & 2.31 & 3.46 \\
\hline Total & 99.48 & 98.75 & 98.72 & 97.36 & 98.81 & 98.22 & 98.71 \\
\hline
\end{tabular}

Ash samples of the sugarcane mills $B$ and $D$ that produce energy only for self-consumption presented a different granulometry. The ashes from the company $D$ had a coarser grain size than the ashes from the company B. No difference was found among the mills able to produce electricity to sell in the market. The $E$ and $\mathrm{G}$ samples showed a profile that differs from the others, not presenting coarse particulate material retained in mesh sieve 4,000 $\mu \mathrm{m}$. Although, showing a similar profile, the $C$ sample differs from $E$ and $G$, retaining particles in the mesh sieve of $2,800 \mu \mathrm{m}$.

The particle size of the samples retained in the sieve mash of $4,000 \mu \mathrm{m}$ can be seen in Figure 2 . These pictures confirm the difference in granulometry profile between the samples collected in all seven mills, highlighting some of the samples ( $B$ and $D)$, where it is possible to observe a coarse texture, featuring material partially unburned. The figure shows greater uniformity in the samples with ashes from power plants $A$ and G. 


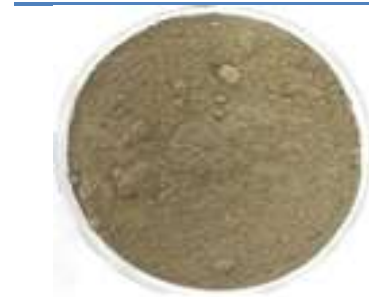

A

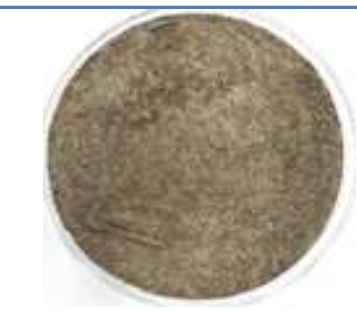

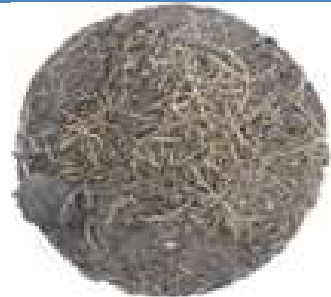

$\mathrm{B}$

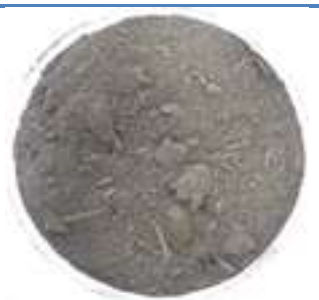

C

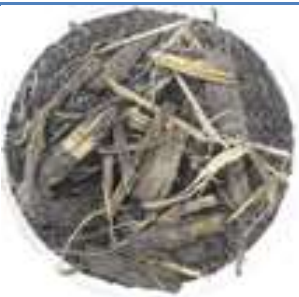

D

Figure 2: Visual characterization of the material retained in 4,000 $\mu \mathrm{m}$ sieve revealing coarse material in seven samples of ash collected in sugarcane industries of Mato Grosso do Sul.

These images can be compared with the microscope pictures under dye to vegetable fibber (Figure 3) and show that in most of the samples it is possible to find inert material, which indicates burning inefficiency in the boilers. These particles may be responsible for the intermediate particle size in the granulometry pattern.

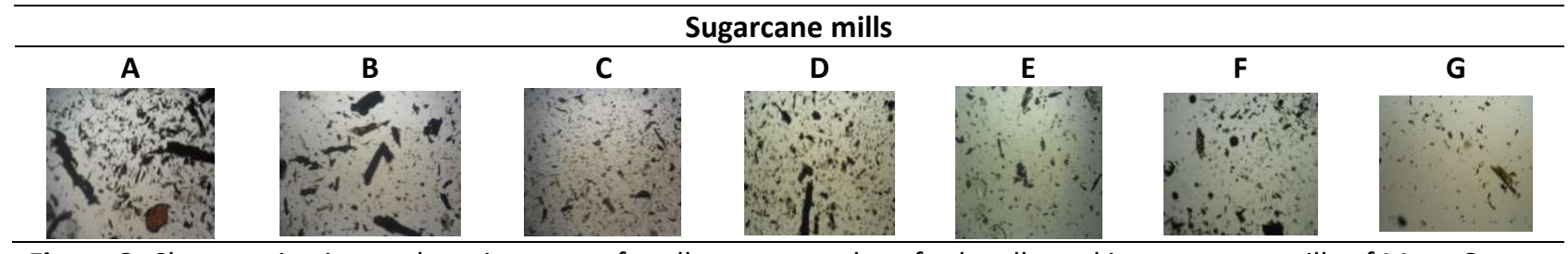

Figure 3: Characterization under microscope for all seven samples of ash collected in sugarcane mills of Mato Grosso do Sul (400X).

The images presented on the Figures 2 and 3 are consistent with the distribution profile of Table 4 , where samples with coarser aspects also displayed higher initial fractions retained in the sieve screens. Another analysis, where is possible to find influence on the particle size of the samples, is the density data presented on Table 5, both simple and tap density.

Table 5: Density, tap density, $\mathrm{pH}$ and total alkalinity of seven samples of ash collected in sugarcane mills from Mato Grosso do Sul (Average of 3 analyzes).

\begin{tabular}{|l|l|l|l|l|}
\hline & Density & Tap density & pH & Alkalinity \\
\hline Sugarcane mills & $(\mathrm{g} . \mathrm{cm}-3)$ & $(\mathrm{g} . \mathrm{cm}-3)$ & & $(\mathrm{mg} / \mathrm{kg} \mathrm{CaCO3)}$ \\
\hline A & $0.56 \mathrm{c}$ & $0.69 \mathrm{c}$ & $10.10 \mathrm{a}$ & $93.33 \mathrm{c}$ \\
\hline B & $0.24 \mathrm{e}$ & $0.26 \mathrm{e}$ & $7.82 \mathrm{e}$ & $453.33 \mathrm{~b}$ \\
\hline C & $0.32 \mathrm{~d}$ & $0.40 \mathrm{~d}$ & $9.18 \mathrm{c}$ & $700.00 \mathrm{a}$ \\
\hline D & $0.28 \mathrm{~d}$ & $0.37 \mathrm{~d}$ & $8.05 \mathrm{~d}$ & $383.33 \mathrm{~b}$ \\
\hline E & $1.11 \mathrm{a}$ & $1.20 \mathrm{a}$ & $8.18 \mathrm{~d}$ & $33.33 \mathrm{c}$ \\
\hline F & $0.24 \mathrm{de}$ & $0.32 \mathrm{de}$ & $7.78 \mathrm{e}$ & $296.66 \mathrm{~b}$ \\
\hline G & $0.61 \mathrm{~b}$ & $0.97 \mathrm{~b}$ & $9.58 \mathrm{~b}$ & $86.66 \mathrm{c}$ \\
\hline
\end{tabular}

Legend: means followed of the same letter in the column do not differ by Turkey's test $p>0.05$.

The data presented on Table 5 shows that there is no significant difference between the density and the tap density values, producing a linear correlation represented by the equation $y=1.1015 x+0.0714$ with 
$r^{2}$ 0.9055, were $y$ is the tap density and $x$ the simple density. It was concluded that the performed analysis of tap density was not necessary to explain ash characteristics.

The density of ash samples allowed the establishment of 5 groups, with the ash from the power plants E representing the densest ash, following by the sample from the mill G. All other samples presented lower density. Regarding to the $\mathrm{pH}$ and alkalinity, the variation on Table 5 could establish only 3 groups. The ash sample $C$ had the highest alkalinity, followed by the ashes from the power plants $B, D$ and $F$. The third group, with lower alkalinity, is composed by the ashes from mills $\mathrm{A}, \mathrm{E}$ and $\mathrm{G}$. The alkalinity and pH may be explained, in part, by the mineral content of the ash samples (Table 6).

Table 6: Minerals in seven samples of ash collected in sugarcane industries of Mato Grosso do Sul (Average of 3 analysis).

\begin{tabular}{|l|l|l|l|l|l|l|l|l|l|l|l|l|}
\hline \multicolumn{1}{|l|}{ Minerals } \\
\hline Sugarcane mills & Ba & Co & Cr & Ni & Cu & Mn & Zn & Na & Fe & \multicolumn{1}{l|}{ K } & Ca & Mg \\
\hline & mgkg-1 \\
\hline & 68.8 & 4.5 & 46.0 & 12.3 & 26.0 & 312.0 & 34.0 & 40.0 & 8.2 & 5.40 & 2.95 & 2.20 \\
\hline A & 74.0 & 3.1 & 44.0 & 15.9 & 36.0 & 462.0 & 84.0 & 462.0 & 7.6 & 5.00 & 1.57 & 3.20 \\
\hline B & 205.1 & 6.5 & 66.0 & 16.0 & 72.0 & 972.0 & 236.0 & 286.0 & 31.8 & 13.80 & 0.69 & 7.40 \\
\hline C & 192.2 & 25.4 & 113.0 & 38.0 & 176.0 & 900.0 & 104.0 & 518.0 & 76.0 & 13.60 & 0.16 & 4.40 \\
\hline D & 30.8 & 9.0 & 17.0 & 8.8 & 32.0 & 240.0 & 32.0 & 44.0 & 17.8 & 2.80 & 0.10 & 1.00 \\
\hline E & 199.8 & 19.1 & 48.0 & 31.0 & 116.0 & 712.0 & 162.0 & 134.0 & 54.2 & 10.40 & 0.35 & 6.60 \\
\hline F & 169.0 & 20.1 & 54.0 & 21.7 & 88.0 & 738.0 & 84.0 & 128.0 & 50.0 & 11.60 & 0.36 & 4.00 \\
\hline G &
\end{tabular}

When the organic matter becomes calcined, it is natural to suffer reduction of its mineral particles, expressed by its oxides. The literature expresses the mineral ashes as their oxides, and highlights (HERNÁNDEZ et al., 1998; FREITAS, 2005; GENESAN et al., 2007; AKRAM, 2009) that the main mineral component is the silicon oxide with a minimum of 62 and a maximum of $83 \mathrm{mg} / \mathrm{g}$ of ash. This fact makes difficult to compare the minor mineral by the results reported in the literature. However, the data show a wide variation among the samples for oxides' content.

Table 6 shows the results of minerals in the ash from sugarcane bagasse, observed in the same range reported in the literature review section (Table 2). It is possible to verify that the ashes collected from the mill E, which produces electricity for selling, presented the lowest values for most of the evaluated minerals, both macro or micro minerals. However, the power plant $\mathrm{G}$, also equipped with boilers capable of generating high temperature steam, did not demonstrate the same profile, with a tendency to present higher levels of minerals, macro or micro.

The Figure 4 shows that the higher concentration of minerals is for barium (Ba), manganese (Mn) and sodium ( $\mathrm{Na}$ ), which were responsible for the individual values of the samples $C, D, F$ and $G$. The sample of ash from the power plants highlights the presence of barium (Ba), copper ( $\mathrm{Cu}$ ) and iron (Fe), whereas the sample D presented contents also of chromium ( $\mathrm{Cr}$ ), nickel $(\mathrm{Ni})$, zinc $(\mathrm{Zn})$ and sodium $(\mathrm{Na})$. Table 7 shows the ash content within the ash and the Higher Calorific Value.

Table 7: Ash content and High Calorific Value of the seven samples of ash collected in sugarcane industries of Mato Grosso do Sul (Average of 3 analysis).

\begin{tabular}{|l|l|l|}
\hline Sugarcane mills & Ash content (\%) & High Calorific Value (kcal/g) \\
\hline A & $98.97 \mathrm{ab}$ & $6,035.02 \mathrm{a}$ \\
\hline B & $95.23 \mathrm{~d}$ & $5,922.16 \mathrm{a}$ \\
\hline C & $98.54 \mathrm{~b}$ & $4,987.44 \mathrm{a}$ \\
\hline D & $97.42 \mathrm{C}$ & $5,897.52 \mathrm{a}$ \\
\hline
\end{tabular}




\begin{tabular}{|l|l|l|}
\hline E & $99.65 \mathrm{a}$ & $0.00 \mathrm{~b}$ \\
\hline $\mathrm{F}$ & $98.29 \mathrm{~b}$ & $6,307.89 \mathrm{a}$ \\
\hline $\mathrm{G}$ & $99.80 \mathrm{a}$ & $0.00 \mathrm{~b}$ \\
\hline
\end{tabular}

Legend: Means followed the same letter in the column do not differ by Turkey test $p>0.05$.

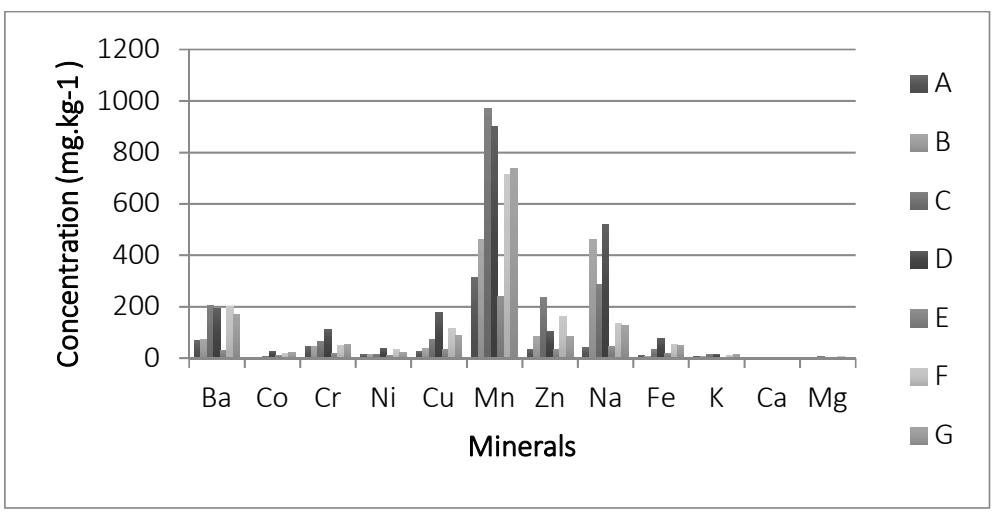

Figure 4: Variation in mineral content to seven samples of ash collected in sugarcane mills of Mato Grosso do Sul.

On Table 7 the results of the ash content analysis within the ash samples show how much material could still burn to generate stabilized ashes. It was expected that all BPST-C system boilers were the most efficient, producing ash with little unburned material, but it was not what happened. It is observed that, although very similar results, four groups can be distinguished. The first group presents the highest levels of ash within the ash and included the two mills that do not sell the electricity ( $B$ and $D$ ) produced by their standard boiler.

When considering the superior calorific value (Table 7), only two sugarcane mills provided higherpressure boiler ( $E$ and $G$ ), showing a mule value. The others showed values between 4,987.44 and 6,307.89, but they are not significantly different. These high values make it clear that boilers still have residual biomass that was not completely burned and are inefficient. These results show that the efficiency of a boiler can be achieved even if the energy produced is only for self-sufficiency and that the three other power plants that sold energy presented material that could potentially be burned, increasing the yield of energy.

Table 8: Colour by Hunter system methodology in seven samples of ash collected in sugarcane mills from Mato Grosso do Sul (Average of 3 analysis).

\begin{tabular}{|l|l|l|l|l|}
\hline Sugarcane mills & Brightness (B\%) & Red & Blue & Yellow \\
\hline A & 18.45 & 2.53 & 0.4 & $-_{-}^{*}$ \\
\hline B & 17.98 & 2.90 & $-*_{-}$ & 0.17 \\
\hline C & 24.21 & 1.81 & $-_{-}$ & 3.75 \\
\hline D & 15.97 & 2.64 & 0.58 & $-*_{-}$ \\
\hline E & 22.93 & 2.73 & $-*_{-}$ & 2.55 \\
\hline F & 17.32 & 2.50 & 0.54 & $-_{-}$ \\
\hline G & 23.60 & 2.91 & $-*_{-}$ & 4.77 \\
\hline
\end{tabular}

Legend: L: Brightness (0 to 100\%); -*-: without values for the tonalities.

Finally, the colour of ash samples is presented on Table 8. Although hardly used to characterize the ashes of boilers, it is observed that the samples collected in the mills $C$, E and G presented the highest brightness. All samples showed tones of red, but the ashes of two plants that presented null values for High Calorific Value (E and G), as well as high red hue value (2.73 and 2.91), presented yellow tone but not blue tone. Higher brightness also appeared in the samples of plants $C$, showing the greatest luminosity; although the samples from $A$ and $D$ had blue tone, they presented low brightness. 


\section{CONCLUSIONS}

The results show that only the ashes of two plants with the BPST system and steam pression higher than 60 bar and surplus electricity, for exportation in the commercial network, differed from the null High Calorific Value. It was also observed that the samples presented particle size smaller than the mesh 4,000 um, highest density, higher ash content within the ashes and higher brightness with red tones. They also presented blue tones, but not yellow tones.

The null value for Superior Calorific Value was presented only in two ashes of the power plants able to co-generate surplus electricity, indicating that the samples were burned completely. In the unavailability of a calorimeter, the analysis of ash content within the ash may be considered an indicator of the efficiency of the boiler. However, it is necessary to remember that a conventional boiler may be also efficient, but in the 2 samples collected in this type of boiler none of them have reached at least 5,900.00 Kcal/kg. These results show that the efficiency of a boiler can be achieved even if the energy produced is only for selfsufficiency and show that the three other mills that sell energy presented material that could potentially be burned, increasing the yield of energy.

\section{REFERENCES}

ABNT. NBR NM 248/2003: Agregados: Determinação da composição granulométrica. Rio de Janeiro, 2003.

ABNT. NBR NM 6457/1986: Amostras de Solo: Preparação para ensaio de compactação e ensaios de caracterização. Rio de Janeiro, 1986.

AHMARUZZAMAN, M.. A review on the utilization of fly ash, Prog. Energy Combust. Sci., v.36, p.327-363, 2010. DOI: http://doi.org/10.1016/j.pecs.2009.11.003

AKRAM, T.; MEMON, S. A.; OBAID, H.. Production of low cost self-compacting concrete using bagasse ash. Science Direct, Elsevier. Construction and Building Materials, v.23, p.703712, 2009. DOI:

http://doi.org/10.1016/j.conbuildmat.2008.02.012

ALVES, M.; PONCE, G. H. S. F.; SILVA, M. A.; ENSINAS, A. V.. Surplus electricity production in sugarcane mills using residual bagasse and straw as fuel. Energy, v.91, p.751-757, 2015. DOI: http://doi.org/10.1016/i.energy.2015.08.101

APHA. Standard methods for the examination of water and wastewater. $19 \mathrm{ed}$. Washington, 1995

BHANDARI, B. R.; SENOUSSI, A.; DUMOULIN, E. D.; LEBERT, A.. Spray drying of concentred fruit juices. Drying Technol, p.1081-1092, 1993. DOI:

http://doi.org/10.1080/07373939308916884

CARRIER, M.; HARDIEB, A. G.; URASA, U.; GÖRGENSA, J.; KNOETZE, J. H.. Production of char from vacuum pyrolysis of South-African sugar cane bagasse and its characterization as activated carbon and biochar. Journal of Analytical and Applied Pyrolysis, v.96, p.24-32, 2012. DOI: http://doi.org/10.1016/j.jaap.2012.02.016

CORTEZ, L. A. B.; LORA, E. E. S.; AYARZA, J. A. C.. Biomassa no
Brasil e no mundo. In: CORTEZ, L. A. B.; LORA, E. E. S.; GOMES, E. O.. Biomassa para energia. Campinas: UNICAMP, 2008.

DESHMUKH, R.; JACOBSON, A.; CHAMBERLIN, C.; KAMMEN, D.. Thermal gaseification or direct combustion. Comparison of advanced cogeneration system in sugarcane industry. Biomass and Bioenergy, v.5, n.5, p.163-174, 2013. DOI: http://doi.org/10.1016/j.biombioe.2013.01.033

DOAT, J.. Le Pouvoir Calorifique des Bois Tropicaux. Bois et Forêts des Tropiques, Nogent-Sur-Marne, n.172, p.33-55, 1977. DOI: http://doi.org/10.19182/bft1977.172.a19325

DUXSON, P.; PROVIS, J. L.. Designing precursors for geopolymer cements. Journal of the American Ceramic Society, v.91, p.3864-3869, 2008. DOI: http://doi.org/10.1111/j.1551-2916.2008.02787.x

FAOSTAT. Food and Agiculture Organization of the United Nations. Production. 2010.

FREITAS, E. S.. Caracterização da cinza do bagaço da canade-açúcar no município de Campos dos Goytacazes para uso na construção civil. Dissertação (Mestrado em Engenharia Civil) - Universidade Estadual do Norte Fluminense, Campos do Goyatacezes, 2005.

GABRA, M.; PETTERSSON, E.; BACKMAN, R.; KJELLSTROM, B.. Evaluation of cyclone gasifier performance for gasification of sugar cane residue e part 1: gasification of bagasse. Biomass Bioenergy, v.21, p.351-369, 2001. DOI: http://doi.org/10.1016/S0961-9534(01)00043-5

GANESAN, K.; RAJAGOPAL, K.; THANGAVEL, K.. Evaluation of bagasse ash as corrosion resisting admixture for carbon steel in concrete. Anti-corrosion Methods and Materials, v.54, n.4, p.230-236, 2007. DOI: 


\section{http://doi.org/10.1108/00035590710762375}

HERNÁNDEZ, J. F.; MIDDENDORF, B.; GEHRKE, M.; BUDELMANN, H.. Use of waste of the sugar industry as pozzolana in lime-pozzolana binders: study of the reaction. Cement and Concrete Research, v.28, n.11, p.1525-1536, 1998. DOI: http://doi.org/10.1016/S0008-8846(98)00130-6

HUGOT, E.. Handbook of cane sugar engineering. 3 ed. New York: Elsevier Science Publishing Company, 1986.

LIZCANO, J. V.. Poder calorífico, energia e cinzas da biomassa de cana-de-açúcar irrigada por gotejamento, para diferentes variedades, lâminas e processos de maturação. Dissertação (Mestrado em Ciências) - Escola Superior de Agricultura 'Luiz de Queiroz', Piracicaba, 2015.

MALAVOLTA, E.; VITTI, G. C.; OLIVEIRA, S. A.. Avaliação do Estado Nutricional das Plantas: princípios e aplicações. 2 ed. Piracicaba: POTAFOS, 1997.

MAPA. Ministério da Agricultura, Pecuária e Abastecimento. Análise de corretivos, fertilizantes e inoculantes: métodos oficiais. Brasília: MAPA, 1988.

MONCADA, J.; EL-HALWAGI, M. M.; CARDONA, C. A.. Techno-economic analysis for a sugarcane biorefinery: Colombian case. Bioresource Technology, v.135, p.533-543, 2013. DOI: http://doi.org/10.1016/i.biortech.2012.08.137

PELLEGRINI, L. F.; OLIVEIRA JÚNIOR, S.. Combined production of sugar, ethanol and electricity: Thermoeconomic and environmental analysis and optimization. Energy, n.36, p.3704-3715, 2010. DOI: http://doi.org/10.1016/j.energy.2010.08.011

SALES, A. S.; LIMA, S. A.. Use of Brazilian sugarcane bagasse ash in concrete as sand replacement. Waste Management, v.30, p.1114-1122, 2010. DOI:

http://doi.org/10.1016/i.wasman.2010.01.026

SAMANIEGO, M. R.. Uso do biocombustível da pirolise rapida da palha de cana em um motor de ciclo Otto. Dissertação (Mestrado em Planejamento de Sistemas Energéticos) - Universidade Estadual de Campinas, Campinas, 2007

SEABRA, J. E. A.. Avaliação técnico-econômica de opções para o aproveitamento integral da biomassa de cana no Brasil. Tese (Doutorado em Planejamento de Sistemas Energéticos) - Universidade Estadual de Campinas, Campinas 2008.

SOUZA, G. N.; FORMAGINI, S.; CUSTÓDIO, F. O.; SILVEIRA, M. $M$.. Desenvolvimento de argamassas com substituição parcial do cimento Portland por cinzas residuais do bagaço de cana-de-açúcar. IN: CONGRESSO BRASILEIRO DO CONCRETO, 49. Anais. São Paulo: IBRACON, 2007.

SPADOTTO, C. A.; RIBEIRO, W. C.. Gestão de resíduos na agricultura e na agroindústria. Aproveitamento de resíduos da indústria sucroalcooleira. Embrapa Meio Ambiente, 2006.

TAPPI. Technical Association of Pulp and Paper Industry. Standard Method T211 om-88. TAPPI Test Methods, 1988.

TASTAN, E. O.; EDIL, T. B.; BENSON, C. H.; AYDILEK, A. M.. Stabilization of organic soils with fly ash. Journal of Geotechnical and Geoenvironmental Engineering, v.137, p.819-833, 2011. DOI: http://doi.org/10.1061/(ASCE)GT.1943-5606.0000502

BIOSUL. União dos Produtores de Bioenergia. Relatório de encerramento de safra, 2014/2015. São Paulo: BIOSUL, 2015.

A CBPC - Companhia Brasileira de Produção Científica (CNPJ: 11.221.422/0001-03) detém os direitos materiais desta publicação. Os direitos referem-se à publicação do trabalho em qualquer parte do mundo, incluindo os direitos às renovações, expansões e disseminações da contribuição, bem como outros direitos subsidiários. Todos os trabalhos publicados eletronicamente poderão posteriormente ser publicados em coletâneas impressas sob coordenação da Sustenere Publishing, da Companhia Brasileira de Produção Científica e seus parceiros autorizados. Os (as) autores (as) preservam os direitos autorais, mas não têm permissão para a publicação da contribuição em outro meio, impresso ou digital, em português ou em tradução. 